\title{
Fruit Breeding for the Northern Great Plains at the University of Minnesota and South Dakota State University
}

\author{
James Luby \\ Department of Horticultural Science, University of Minnesota, St. Paul, MN 55108 \\ Anne Fennell \\ Department of Horticulture, Forestry, Landscape and Parks, South Dakota State University, Brookings, SD 57007
}

As 19th century settlers on the northern Great Plains discovered, this region was one of the most inhospitable of any in the young nation for fruit production. Through the early 20th century this was a region with hundreds of thousands of small farms. The fruit from the farm orchard was eaten fresh in the summer, canned or dried for the winter, used to produce fermented beverages such as hard cider or apple jack, and sometimes provided additional income. More importantly, it provided critical nutritional components, as well as delight, in a sometimes bland and monotonous diet. However, the new farmers of the region soon realized that many fruit cultivars they brought from the eastern U.S. or from their native regions of Europe failed in the harsh winters and droughty summers of the continental climate. Consequently, they organized into state horticultural societies that developed lists of recommended cultivars based on members' experiences and also identified needs for new cultivar development. The Minnesota State Horticultural Society and the South Dakota State Horticultural Societies encouraged their legislatures to address the critical lack of adapted fruit cultivars by establishing productive fruit breeding programs at the experiment stations and land grant colleges in their respective states.

\section{MINNESOTA}

The initiation of fruit breeding at the University of Minnesota was due in large measure to success of the colorful and controversial Peter M. Gideon in developing the first great apple variety from the northern plains (Curran, 2004). Gideon had arrived in Minnesota in 1853 with many fruit trees to test and a bushel of apple seeds to plant. By 1868, he had identified an outstanding seedling, eventually named the 'Wealthy' apple after his wife, which became one of the most important cultivars in the United States by the late 1800 s and early 1900 s. Indeed, it was primarily due to his success in developing and commercializing 'Wealthy' that the state legislature agreed to fund a breeding program.

Fruit breeding at the University of Minnesota has been ongoing since 1878 when the legislature of the 20-year-young state appropriated the grand sum of $\$ 2000$ to purchase a tract of land as an experiment station and $\$ 1000$ per year for operations. Gideon was named the first superintendent of the new station, located near his farm on Lake Minnetonka at Excelsior, Minn. Unfortunately,
Peter Gideon and University administrators had their differences. Gideon felt that he was not given appropriate support or recognition while university administrators thought the he operated the station too independently. Gideon directed the program until 1889 when he retired at age 70 and the station was abandoned. A later University of Minnesota fruit breeder, William Alderman, noted that the mere 10 years that the Minnetonka Fruit Farm was open was too short for productive results. He lamented the politics of the day but lauded Gideon: "It is unfortunate that clashing personalities prevented him from assuming a more constructive leadership in the great fruit breeding program that was to develop through the region. Be that as it may, he still must be recognized as the "father of fruit breeding on the prairies" (Alderman, 1962).

While Peter Gideon managed the program in Excelsior, Samuel B. Green, the first professor of horticulture at the University of Minnesota, began crossing apples in 1888 and grew the seedlings at the University Farm in St. Paul, which has now become the University of Minnesota, St. Paul campus. Green spent some time evaluating apples but eventually became more interested in forest management as the great pine forests of northern Minnesota were being cut and is now honored as the father of modern forestry in Minnesota.

In 1907, the legislature appropriated land to establish a new fruit breeding farm between Excelsior and Chaska, about 33 miles southwest of Minneapolis-St. Paul and this became the center of fruit breeding for the next century. The farm was continually staffed with a superintendent and knowledgeable horticultural technicians who took active roles in the fruit breeding. Through the early 20th century, several faculty taught on the St. Paul campus and then in the summer traveled to the Fruit Breeding Farm by streetcar to conduct fruit breeding research. Usually they would stay in one of several cabins at the farm during the summer months, even bringing their families, thus using it as their summer research retreat.

Through this period, numerous people were involved in fruit breeding. A tradition, established during the long leadership of William $\mathrm{H}$. Alderman was to encourage recognition of the program rather than individuals. The superintendent of the Fruit Breeding Farm was a key position in early times when transportation from campus was more difficult. Charles Haralson was appointed as the first superintendent. Haralson had been an assistant to Niels
Hansen, the fruit breeder at South Dakota State College, and was honored with the naming of the 'Haralson' apple, which became the most important cultivar for several decades. Other notable assistant superintendents and technicians who were actively involved in the fruit breeding efforts included Frederick Haralson, Patrick Pierquet, and Elmer Swenson. Although he spent a short time at the University of Minnesota, Swenson was especially known for his independent grape breeding efforts and is considered the godfather of cold hardy grape breeding. He began breeding grapes on his western Wisconsin dairy farm after World War II. A gentle, humble man, and carefully self-educated plant breeder, he made great progress in developing hardy grape hybrids based on the local riverbank grape, Vitis riparia, crossed with French and American hybrids. His legacy continues with the program at the University of Minnesota as well as with several local private grape breeders. Several of his cultivars, 'St. Croix', 'La Crosse', 'St. Pepin', 'Brianna', 'Sabrevois', and others, are grown in the midwestern U.S. and cold regions of the northeastern U.S. and Canada.

Several University of Minnesota faculty provided leadership to the fruit breeding programs (Snyder, 1982). Following the death of Samuel Green in 1910, M.J. Dorsey was named associate professor of fruit breeding on the St. Paul campus and served until 1921. Other faculty involved in the fruit breeding through the 20th century included W.H. Alderman (1919-1953), J.H. Beaumont (1919-1928), A.N. Wilcox from 1923-1963, T.S. Weir(1939-1966), and William Anderson (1964-1966). More than 90 fruit cultivars were introduced, beginning in the 1920s. During the early decades, introductions were focused on apples, plums and related Prunus, as well as small fruits. Several introductions became regionally, nationally or even internationally popular. 'Latham' raspberry, for example, propelled Minnesota to be the third ranked state in the U.S. in raspberry acreage by the 1940s with a crop value of over a million dollars annually. It became widely grown in eastern North America and colder parts of Europe. 'Trumpeter' strawberry and 'Haralson' and 'Beacon' apples became regional favorites. The 'North Star' and 'Meteor' tart cherries and the 'Red Lake' currant were widely grown in North America and Europe. 'Sungold' and 'Moongold' apricots, 'Parker' pear, and a host of plums remain regionally popular to this day in home landscapes and gardens.

Cecil Stushnoff led the program from 
1967-1980. Though he maintained a large emphasis on apples, his experience as a graduate student in New Jersey also inspired an attempt to develop large-fruited, productive blueberries for cold climates. This led to a string of winter hardy half-high to $3 / 4$-high cultivars that allowed a commercial direct-market blueberry production in U.S Department of Agriculture (USDA) hardiness Zones 4 and 3. 'Northblue' and, more recently, 'Chippewa' and 'Polaris' have become the most popular commercial cultivars.

In the late 20th and early 21 st centuries, the breeding program has focused on apple, grape, blueberry and strawberry breeding. James Luby has overseen the fruit breeding program since 1982 along with David Bedford, in apple breeding, David Wildung, in berry breeding, and Peter Hemstad, who invigorated the grape breeding effort in 1985. This period has been marked by the introduction of 'Honeycrisp', the first apple introduction from the program to gain worldwide interest, 'Mesabi' strawberry, and 'Frontenac' and 'La Crescent', the first high quality wine grapes from the program..

William H. Alderman has probably been the most important historical leader in the fruit breeding program and certainly the longest serving. He arrived at the University of Minnesota in 1919 to serve as department head and lead the fruit breeding efforts until his retirement in 1953 . He was born in western New York, graduated from the Agricultural College of Cornell University. He was a horticulturist for a year at the New York State Agricultural Experiment Station at Geneva, then was head of the Horticulture Department at West Virginia University for eight years before coming to Minnesota. At the University of Minnesota, he oversaw the staffing and development of the fruit breeding programs for over three decades. According to an obituary published in Minnesota Horticulturist (13:240-241) when he died in 1985 at 100 years of age, Alderman was universally respected at the University of Minnesota and in the horticultural community of the state. He was described as a calm, wise, tolerant, and, above all, kind man and earned the respect and affection of his students and staff by his genuine concern and regard for them. Among his academic peers in the northern Great Plains he was recognized by W.R. Leslie, a researcher and administrator at the Morden (Manitoba) Experimental Farm for his "wise counsel, ... gifted talent for organizing scientific effort, unlimited cooperation..." and "warmly esteemed as our horticultural Chieftain..." (Alderman, 1962).

\section{SOUTH DAKOTA}

Fruit breeding at the South Dakota State College (now South Dakota State University) has largely been synonymous with one of the most illustrious plant explorers of the northern temperate regions of the world. He not only introduced and bred fruit plants, but also vegetables and ornamentals, grains and forages.
Niels Hansen emigrated from Denmark to the U.S. as a child, settling finally in Des Moines, Iowa. He received bachelors and masters degrees from the Department of Horticulture at Iowa State College and began his career in South Dakota in 1895 at the experiment station that was founded at Brookings a few years earlier in 1887.

Throughout his long career from 1895 until 1937 Hansen worked with a singleness of purpose to bring to "South Dakota and the Northern Great Plains region the world's wealth of horticultural plants and crops grown in the higher latitudes of the North Temperate Zone"(Alderman, 1962). He was a well known plant explorer in a golden age of plant exploration. Between 1897 and 1934 he made six exploration trips to northern Europe and Asia that were funded by the USDA or the state of South Dakota. In 1897, he was the first Plant Explorer appointed in the USDA, a corps that included several other famous horticultural explorers such as USDA Chief of Foreign Seed and Plant Introduction David Fairchild, Frank N. Meyer, and Wilson Popenoe. Some people, including other plant explorers of the day such as Fairchild and Meyer, complained that Hansen spent too lavishly on his trips. However, Hansen, who seemed to operate with the philosophy of spend now, apologize later, nearly always returned with huge amounts of seeds and plant material. Among his most important fruit introductions were the siberian crabapple, Malus baccata, the red-fleshed central asian apple, $M$. sieversii var. niedzwetzkyana, the hardy asian pear, Pyrus ussuriense, and hardy manchurian and siberian apricots. He also brought back several other Prunus species that were later hybridized with North American species (Hansen, 1927).

In addition to his Asian explorations, Hansen also made numerous collecting trips through the Great Plains of the northern U.S. and Canada. He collected wild riverbank grape, Vitis riparia, and crossed it with several eastern V. labrusca-derived cultivars to produce a series of selections that were widely grown in the region. He also focused on native Prunus species including the sandcherry, $P$. besseyi, the plums, $P$. americana and $P$. nigra, which he crossed with Asian species such as the prized japanese plum, $P$. salicina, as well as several other bush-type species.

At the Experiment Station in Brookings, according to S.A. McCrory (Alderman, 1962), Hansen had a very small budget and little help. To make the most of these limited resources, his mode of operation was to grow massive numbers of seedlings from his explorations or hybridizations (more than 100,000 were growing in 1903), select those that appeared to be the most promising, propagate them, name them, and describe them in annual catalogs from the experiment station. People could order these selections, paying a nominal fee, and grow them as part of what was essentially a huge region-wide testing network. Hansen would update the descriptions of some of these cultivars based on observations that were reported back to him.

Altogether, 363 plant cultivars were introduced from Hansen's introductions and hybridizations. He introduced 340 and another 23 were introduced following his retirement. Hansen's introductions included 271 fruit and nut cultivars. These included apples, crabapples, pears, apricots, various Prunus species and hybrids such as plums, sandcherries, cherry plums, grapes, blackcurrants, gooseberries, raspberries, walnuts, hazelnuts, and others (Hansen, 1927, 1937). Probably the best known and widely grown in the region are the 'Dolgo' and 'Hopa' crab apples, the 'Sapa' and 'Opata' cherry-plums, 'Waneta' and 'Toka' plums, 'Sioux' sandcherry, and 'Anoka' apple.

The period immediately following Hansen's retirement saw little fruit breeding activity at South Dakota State College. McCrory made a critical contribution by conserving what was considered the most valuable of Hansen's introduction in an arboretum at the experiment station. In 1956, Ronald M. Peterson, trained in fruit breeding with a $\mathrm{PhD}$ from the University of Minnesota, arrived and continued fruit breeding. He was particularly interested in apples, pears and grapes. Using hardy $P$. ussuriensis selections identified by Hansen, he introduced two pear varieties in the 1970s and 1980s, 'Luscious' and 'Gourmet', that are widely planted in gardens of the region today. Also in the tradition of Hansen, Peterson did much exploration and collection of the local fruiting plants of the region including red and black raspberries from the Black Hills and the wild riverbank grape of the northern Great Plains, Vitis riparia. Many of his collections are now in USDA collection of cold hardy grapes housed at the Plant Genetic Resources Unit at Geneva, N.Y. One of these accessions from Montana, the far western edge of the species range, was crossed with 'Fredonia' to produce 'Valiant', a table grape that is popular in the region. Peterson was a kind, gentle and patient professional. He always had a sparkle in his eye and enthusiasm in his voice when he talked about the fruit breeding program at South Dakota State. Following his retirement from the University in 1987, he continues to manage a small orchard near Brookings.

\section{Literature Cited}

Alderman, W.H. 1962. Development of horticulture on the northern Great Plains. Great Plains Reg. Amer. Soc. Hort. Sci.

Curran, J.R. 2004. The great American apple wizard: The life and times of Peter Gideon. Endeavor Publ., Salisbury, Md.

Hansen, N.E. 1927. Plant introductions. S. Dak. State College Agr. Mech. Arts Expt. Sta. (Brookings) Bul. 224.

Hansen, N.E. 1937. Fruits, old and new and northern plant novelties. S. Dak. State CollegeAgr. Mech. Arts Expt. Sta. (Brookings) Bul. 309

Snyder, L.C. 1982. History of the Department of Horticultural Science and Landscape Architecture 1849-1982. Minn. Agr. Expt. Sta., St. Paul. 